\author{
Zeka Pehlevan \\ Elif Nilay Ada Daşdan \\ Mersin University, Mersin-Turkey \\ zpehlivan@mersin.edu.tr, elifnilayada@gmail.com
}

http://dx.doi.org/10.12739/NWSA.2017.12.2.2B0108

BEDEN EĞİTIMINDE "DİSIPLIN SAĞLAMA STRATEJİLERI ÖLÇEĞİNİN TÜRK ÖĞRENCİLER İ̧̧IN GEÇERLIK VE GÜVENIRLIK ANALIZİ

öz

Bu çalışmanın amacı; Disiplin Sağlama Stratejileri Ölçeği'nin (DSSÖ) Türk öğrenciler için geçerlik ve güvenirlik analizlerinin yapılmasıdır. Çalışma grubunu dört ayrı okuldan 298'i kız (X $\left.x_{y a s ̧}=12.84 \pm 1.16\right), 278^{\prime} i$ erkek $\left(\mathrm{X}_{\text {yas }}=12.90 \pm 1.10\right)$ olmak üzere toplam 575 (X öğrencisi gönüllü olarak oluşturmuştur. Veriler, Disiplin Sağlama Stratejileri Ölçeği ile toplanmıştır. Verilerin analizinde Açıklayıcı (AFA) ve Doğrulayıcı Faktör Analizi (DFA) teknikleri uygulanmıştır. Ölçeğin geçerliğine yönelik yapılan AFA analizlerine göre DSSÖ'nün özgün formuna uygun olarak dört faktörlü bir yapı oluşturduğu ve bu faktörlerin toplam varyansın 52.96'sını açıkladığı, DFA analizi sonuçları da ölçeğin önerilen uyum indeks değerlerine göre ( $\left.x^{2} / \mathrm{sd}=2.23, \mathrm{RMSEA}=0.046, \mathrm{p}<.001\right)$ iyi uyum sağladığı görülmüştür. Ölçeğin iç tutarlık katsayısını hesaplamaya yönelik yapılan Cronbach alfa değerleri "içsel" faktörü için .92, "dışsal/sorumluluk" faktörü için .84, "kayıtsızlık" faktörü için .71 ve "içe yansıtma" faktörü için ise .65 olarak bulunmuştur. Sonuç olarak, adaptasyonu yapılan ölçeğin ortaokul 10-15 yaş grubu için geçerli ve güvenilir olduğu bulunmuştur.

Anahtar Kelimeler: Disiplin Sağlama Stratejisi, Beden Eğitimi, Geçerlik, Güvenirlik, Ölçek

\title{
VALIDITY AND RELIABILITY ANALYSIS FOR TURKISH STUDENTS TO "STRATEGIES TO SUSTAIN DISCIPLINE SCALE" IN PHYSICAL EDUCATION
}

\section{ABSTRACT}

The purpose of this study is analysis of validity and reliability of the Discipline Sustain Strategies Scale (SSDS) for Turkish students. A total of $575\left(\mathrm{M}_{\mathrm{age}}=12.86 \pm 1.13\right)$ secondary school students voluntarily formed the study group from 298 girls $\left(\mathrm{M}_{\mathrm{age}}=12.84 \pm 1.16\right)$ and 278 boys $\left(M_{\text {age }}=12.90 \pm 1.10\right)$ from four separate schools. Data were collected by the Discipline Sustain Strategies Scale. Explanatory Factor Analysis (EFA) and Confirmatory Factor Analysis (CFA) techniques were applied in the analysis of the data. According to the EFA analyzes of the scale, as the original form of SSDS, the EFA constituted a four-factor structure and these factors explained 52.96\% of the total variance. The results of the CFA analysis showed that according to the fit index values $\left(x^{2} / \mathrm{sd}=2.23\right.$, RMSEA $0.046, \mathrm{p}<.001)$. The Cronbach alpha values for calculating the internal consistency coefficient of the scale were found to be .92 for "internal" factor, .84 for "external/responsibility" factor, .71 for "indifference" factor and .65 for "introjected" factor. As a result, the adaptation scale was found to be valid and reliable for the 10-15 age group of secondary school.

Keywords: Discipline Sustain Strategy, Physical Education, Validity, Reliability, Scale 


\section{GIRIŞ (INTRODUCTION)}

Öğretmenler okul ve sınıf ortamında çeşitli rollere sahiptir. Bu rollerin en önemlisi ise sınıf yönetimidir. Sınıf yönetimin zayıf olduğu bir sınıf ortamında etkili öğrenme ve öğretimin olması da beklenemez. Sınıf yönetimini etkileyen çevresel faktörler ise çocukların özellikleri, akran ilişkileri ve akran kültürü, sınıfın fiziksel ve psikososyal yapısı, öğretmenin kişisel ve mesleki özellikleri, okul yapısı, aile, toplumsal, kültürel ve sosyal çevre ve kitle iletişim araçları gösterilmektedir (Yaşar, 2016). İyi bir sınıf yönetiminin olduğu sınıfta ise öğrencilerin öğrenme düzeyinin artacă̆ı bir öğretim ortamı da sağlanmış olacaktır. İyi bir öğrenme ortamının oluşması için uygun bir sınıf yönetiminin gerçekleşmesi gerekir ki bunun için üst düzeyde bir çabanın gösterilmesine gereksinim duyulacaktır ve bu çabayı gösterecek olan kişi de öğretmendir (Ünlü ve Aydos, 2008).

Uygun bir sınıf atmosferinin olmaması disiplinle ilgili sorunlara neden olabilir. Sınıf ortamında öğrenme-öğretme sürecini olumsuz etkileyen disiplin sorununun çözümü öğrenmeye harcanacak zamanın artmasına neden olabilmektedir (Gordon, 2000). Sınıf ortamında istenmeyen davranışlarla baş edebilmek sınıf disiplini ile ilgilidir (Aydın, 2006). Sınıf ortamında disiplin kavramı, aynı amacı gerçekleştirmek için bir araya gelmiş öğrencilerin belli bir düzen içerisinde davranmalarını sağlamak için konulmuş kurallara uyumu ve öğrenciye verilen görevleri bir düzen içerisinde yerine getirme olarak ifade edilmektedir (Sarıtaş, 2000; Erdoğan, 2001). Öğretmenler sınıf disiplini sağlamada belli başlı yaklaşım ve stratejilere başvurmaktadırlar. Bu yaklaşımlar; Skinner'in Davranış Değiştirmeye Dayalı Disiplin Yaklaşımı, Canter ve Canter'in Güvengen/Atılgan Disiplin Yaklaşımı, Dreikurs'un Sosyal/Ussal Disiplin Yaklaşımı, Glasser'in Gerçeklik Terapisi Yaklaşımı, Kounin'in Öğretimsel Yaklaşımı (Grup Yönetimi) ve Gordon'un Etkili İletişim Yaklaşımı (Öğretmen Etkililiği Eğitimi Modeli) olarak belirtilmektedir (Sadık, 2016). Ancak sınıf disiplini sağlamada her öğrencinin temel gereksinimlerinin karşılanmasından daha çok kabul edilebilir sınıf davranışlarının öğretmenler tarafından oluşturulması beklenmektedir. Bu da her öğretmenin felsefesi, kişilik özelliği, kullandığı öğretim yöntemi, iletişim kurma biçimi gibi nedenlerle farklı disiplin sağlama yaklaşım ve stratejisi uygulamasına neden olabilmektedir (Charles, 1996). Farklı bir disiplin sağlama stratejisi uygulamak istendik bir durumdur ve öğretmenlerin kendilerine özgü disiplin sağlama stratejisi geliştirmeleri de zor bir iş olmadığı ileri sürülmektedir (Aydın, 2006).

Beden eğitimi sınıflarında çocuklar arasındaki akademik ve sportif rekabet gibi durumlar, diğerlerinin başarılarını kendisine karşı tehdit kabul eden öğrenciler arasında ortaya çıkan disiplin sorunlarını bir nedeni olabilmektedir. Akranların etkisi de çocuklarda sorunlu davranişlar yaratmada etkin bir rol oynayabilmektedir (Humphreys, 2001). Diğer taraftan öğrencilerin disiplinli olma konusunda, nasıl bir sınıf atmosferi algıladığı da son derece önemlidir. Çünkü öğrencilerin beden eğitimi sınıflarında hür iradeleri üzerinde en büyük etkili faktör öğretmen ve onun öğretme stili, öğretme yaklaşımları ve sınıfta disiplini sağlamak için uygulanan farklı stratejilerdir. Beden eğitimi öğretmenleri, doğasında kontrolü sağlayamamış öğrencilere istendik davranışlar kazandırmak için belli başlı disiplin sağlama stratejileri kullanmak zorundadırlar (Gutierrez, Ruiz ve Lopez, 2010). Bunun yanında, birçok beden eğitimi öğretmeninden kalabalık öğrenci gruplarına, yoğun bir içeriği, daha az zaman, daha küçük bir alanda ve daha az araç-gereç ve malzemeyle 
öğretmesi istenmektedir. Bu durum beden eğitimi dersinde sınıf yönetiminin ve disiplinin çoğu zaman kaybolmasına neden olmaktadır (Ünlü ve Aydos, 2008). Disiplinin en rahat kaybolabileceği ortamlardan birisi olan beden eğitimi dersleri, öğrencilerin fiziksel olarak birbirlerine yakınlaşmaları, rekabet ortamı, öğretmenin aynı anda pek çok yerde olamaması ve fiziksel ortamın etkisi gibi nedenler disiplinsizlik kaynağı olarak görülebilir. Bu amaçla Türkçe alan yazın taranmış ancak beden eğitimi derslerine özgü disiplinle ilgili bir ölçme aracına rastlanmamıştır. Bu nedenle bu çalışmanın amacı Papaioannou (1998) tarafından geliştirilmiş olan Disiplin Sağlama Stratejileri Ölçeği'nin (Strategies to Sustain Discipline Scale-SSDS) Türk çocukları için geçerlik ve güvenirlik çalışması yapmaktır.

\section{2. ÇALIŞMANIN ÖNEMI (RESEARCH SIGNIFICANCE)}

Farklı kültürlerde geliştirilen ölçme araçlarının yeniden geliştirilme çalışması yerine başka kültüre ve örneklem grubuna adaptasyonu sağlama çalışmaları yaygın olarak kullanılmaktadır. Bu çalışmada da Yunan kültüründe geliştirilmiş olan beden eğitimi derslerinde Disiplin Sağlama Stratejileri Ölçeği'nin Türk kültürüne uyarlanması hedeflenmiştir. Türkçe alan yazın incelendiğinde bu amaçla geliştirilmiş veya uyarlaması yapılmış her hangi bir ölçme aracına rastlanmamıştır. Bu boşluğu doldurmak ve beden eğitimi öğretmenlerinin derslerinde disiplin sağlamak için ne tür stratejiler uyguladıklarını belirlemek, beden eğitimi öğretmeni yetiştirmede öğretim programlarının ve uygulamaların gözden geçirilmesi açısından önemli olduğu düşünülmektedir.

\section{YÖNTEM (METHOD)}

\subsection{Araştırma Modeli (Research Design)}

Bu çalışma betimsel türde, psikometrik parametreleri belirlemek amacıyla planlanmış bir ölçek uyarlama çalışmasıdır.

\subsection{Katılımcılar (Participants)}

Çalışmaya Mersin ili merkezindeki dört ayrı okuldan yaş ortalaması 12.86, standart sapması 1.13 olan 298'i kız (X=12.84 1.16$)$,

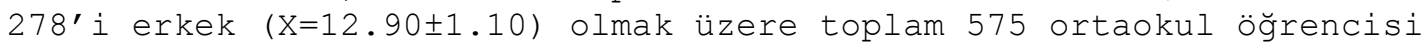
(5. 6. 7. ve 8. sınıf) gönüllü olarak katılmıştır.

\subsection{Verilerin Toplanması (Collecting Data)}

Verilerin toplanmasında Disiplin Sağlama Stratejileri ÖlçeğiDSSÖ (Strategies to Maintain Discipline Scale-SSDS) kullanılmıştır. DSSÖ, beden eğitimi sınıflarında disiplini sağlamak için beden eğitimi öğretmenlerinin kullandıkları disiplin sağlama stratejilerin öğrenciler tarafından nasıl algılandığını ölçmek amacıyla Papaioannou (1998) tarafından geliştirilmiştir. Ölçek toplam 26 madde ve dört alt faktörden oluşmakta ve 5'li Likert'e göre cevaplandırılmaktadır. Ölçek, "Beden eğitimi öğretmeni derste disiplini sağlamak için nasıl davranır?" sorusunu nitelendiren genel bir soru ile başlamaktadır. Cevaplar (1) "Kesinlikle katılmıyorum" ile (5) "Kesinlikle katılıyorum" arasında değişmektedir. Ölçek, öğretmenlerin disiplini sağlamak için içsel nedenleri vurgulaması için "Dersi ilginç hale getirip dikkatimizi canlı tutarak disiplini sağlamaya çalışır", öğretmen disiplini sağlamak için içe yansıtılmış nedenleri vurgulamak için "Derste nasıl geliştiğimize dikkatimizi çekerek dersi öğretir", öğretmen disiplini sağlamak için aldırmaz/ilgisiz olması için "Disiplini sağlamak için hiçbir şey yapmaz" ve öğretmenlerin disiplini sağlamak için dışsal nedenleri vurgulaması için "Uygunsuz davrandığımızda bizi cezalandırmakla korkutarak disiplini sağlamaya 
çalışır" biçiminde örnek maddelerden oluşmaktadır. Özgün ölçeğin iç güvenirlik Cronbach alfa katsayıları "içsel" için .93, "içe yansıtma" için.76, "kayıtsız" için .62 ve "dışsal" için.76'dır. Ölçeğin her bir alt boyutu bağımsız olarak değerlendirilmekte, ölçekten toplam puan alınmamaktadır.

\subsection{Verilerin Analizi (Data Analysis)}

Ölçeğin yapı geçerliğini belirlemede, aynı yapıyı ya da niteliği ölçen değişkenleri bir araya toplayarak ölçmeyi ve az sayıda faktör ile açıklamayı amaçlayan Açıklayıcı Faktör Analizi (AFA) yapılmıştır. Faktör analizinde ise Temel Bileşenler Analizi (Varimax Rotation) yöntemi kullanılmıştır. Elde edilen faktör yapısının uygunluğunu test etmek için de Doğrulayıcı Faktör Analizi (DFA) Lisrel 8.71 versiyonu (Jöreskog ve Sörbom, 2004) kullanılmıştır. DFA analizinde En Çok Olabilirlik (Maximum Likelihood, ML) yöntemi esas alınmıştır. Modelin uyum iyiliğini değerlendirmek için çeşitli uyum indeksi ölçütlerine bakılmıştır. AFA sonrası ölçek ve alt boyutlarının güvenirlik analizlerinde Cronbach's Alpha katsayısı kullanılmıştır. Analizlerde hata payı p<.05 olarak kabul edilmiştir.

\section{BULGULAR (FINDING) \\ 4.1. Geçerlik (Validity)}

- Dil Geçerliği: Ölçeğin dil geçerliği için özgün formu olan İngilizce'den Türkçe'ye çevirisi yapılmıştır. Bu çeviri süreci bir mütercim tercüman, dört doktora dereceli beden eğitimi alan uzmanı akademisyen ve bir Türkçe alanında uzman öğretim üyesinin katılımıyla tamamlanmış ve uyum düzeyi 0.87 olarak sağlanmıştır.

- Açıklayıcı Faktör Analizi (AFA): Açıklayıcı Faktör Analizi (AFA) uygulamasından önce örneklem büyüklüğünün faktörleşmeye uygun olduğunu test etmek amacıyla Kaiser-Meyer-Olkin (KMO) testi uygulanmıştır. Analiz sonucunda KMO değerinin .94 olduğu gözlenmiştir. Bu bulgu doğrultusunda, örneklem büyüklüğünün faktör analizi yapmak için "mükemmel derecede yeterli" olduğu sonucuna ulaşılmıştır (Çokluk, Şekercioğlu ve Büyüköztürk, 2010:207). Ayrıca Bartlett Küresellik Testi sonuçları incelendiğinde, elde edilen ki-kare değerinin anlamlı olduğu görülmüş $\left(x^{2}{ }_{(325)}=6196.5 ; \quad p<.01\right)$ ve verilerin çok değişkenli normal dağılımdan geldiği kabul edilmiştir. Yapılan AFA analiz sonucunda, analize temel olarak alınan 26 madde için öz değeri 1'in üzerinde olan beş bileşen olduğu görülmüştür. Bu bileşenlerin toplam varyansa yaptıkları katkı oranı \%57'dir. Bu aşamada 10. maddenin beşinci faktörde yer aldığı gözlenmiştir. Söz konusu bu beş bileşen, gerek açıklanan toplam varyans değerleri ve gerekse yamaç-birikinti grafiği (Scree Plot) de incelenerek, toplam varyansa yaptıkları katkının önemi ve orijin ölçek bileşen sayısı da dikkate alınarak ölçek dört faktöre zorlanarak analiz tekrar edilmiştir. Bu karar, aracın uyarlanması sürecinde orijinal ölçeğin faktör yapısına uyumlu olması açısından da anlamlı olduğu görülmüştür. Dört faktör için tekrarlanan analiz sonucunda açıklanan toplam varyans oranı 53 olarak belirlenmiştir. Açıklanan toplam varyans oranının sosyal bilimlerde ve çok değişkenli verilerde \%30'un üstünde olması önerilmektedir (Gliner, Morgan ve Leech, 2015). Bu durumda elde edilen varyans oranının iyi düzeyde olduğu söylenebilir. Faktör analizi sonuçlarını değerlendirmede temel ölçüt faktör yükleridir. Faktör yüklerinin yüksek olması, değişkenin söz konusu faktör altında yer alabileceğinin bir göstergesi olarak görülür. Bu araştırmada bir maddenin bir faktörde 
gösterilebilmesi için en az .35'lik faktör yüküne sahip olması ile sınırlandırılmıştır. Bununla birlikte madde seçiminde maddelerin bulundukları faktördeki yük değerleri ile diğer faktörlerdeki yük değerleri arasındaki farkın.10 ve daha büyük olmasına da dikkat edilmiştir. Orijinal ölçek yapısına uygun olarak, ölçeğin dört faktör altında toplandığı görülmüştür. Tablo 1'de faktörlere ait yük değerleri ile maddelere ait varyansları verilmiştir.

Tablo 1. Temel bileşenler analizi dik döndürme (varimax) sonucu faktör deseni

(Table 1. Principal component analysis vertical rotation (varimax) result factor design)

\begin{tabular}{|c|c|c|c|c|c|}
\hline Madde No & $\begin{array}{c}\text { Faktör } \\
1\end{array}$ & $\begin{array}{c}\text { Faktör } \\
2\end{array}$ & $\begin{array}{c}\text { Faktör } \\
3\end{array}$ & $\begin{array}{c}\text { Faktör } \\
4\end{array}$ & $\begin{array}{c}\text { Faktör Ortak } \\
\text { Varyansı }\end{array}$ \\
\hline 1 & .46 & & & & .41 \\
\hline 17 & .69 & & & & .65 \\
\hline 18 & .61 & & & & .54 \\
\hline 19 & .75 & & & & .67 \\
\hline 20 & .66 & & & & .53 \\
\hline 21 & .71 & & & & .57 \\
\hline 22 & .76 & & & & .61 \\
\hline 23 & .73 & & & & .62 \\
\hline 24 & .63 & & & & .45 \\
\hline 25 & .71 & & & & .57 \\
\hline 26 & .72 & & & & .60 \\
\hline 5 & & .63 & & & .51 \\
\hline 8 & & .59 & & & .52 \\
\hline 9 & & .58 & & & .54 \\
\hline 13 & & .64 & & & .50 \\
\hline 15 & & .62 & & & .51 \\
\hline 16 & & .58 & & & .60 \\
\hline 2 & & & .60 & & .57 \\
\hline 4 & & & .63 & & .48 \\
\hline 6 & & & .65 & & .45 \\
\hline 10 & & & .39 & & .23 \\
\hline 12 & & & .56 & & .34 \\
\hline 14 & & & .74 & & .56 \\
\hline 3 & & & & -.68 & .58 \\
\hline 7 & & & & -.71 & .59 \\
\hline 11 & & & & -.59 & .57 \\
\hline Özdeğer & 8.88 & 2.34 & 1.43 & 1.11 & \\
\hline Açıkladığı Varyans & 34.16 & 9.01 & 5.51 & 4.27 & \\
\hline Toplam Varyans & 34.16 & 43.17 & 48.69 & 52.96 & \\
\hline
\end{tabular}

Tablo 1 incelendiğinde yapının orijinal ölçekteki faktör yapısı gibi dört faktör altında toplandığı görülmektedir. Faktörlerin açıkladığı toplam varyans oranları incelendiğinde birinci faktörün ○34.16, ikinci faktörün \%9.01, üçüncü faktörün $\% 5.51$ ve dördüncü faktörün ise $\frac{0}{4.27}$ olduğu, faktörlerde yer alan maddelerin faktör yükleri incelendiğinde de birinci faktörün .46 ile.76, ikinci faktörün .58 ile.64, üçüncü faktörün.39 ile.74 ve dördüncü faktörün ise .59 ile .71 arasındadır. AFA sonucunda, Faktör 1 altında 11 madde $(1,17,18,19,20,21,22,23,24,25,26)$, faktör 2 altında altı madde $(5,8,9,13,15,16)$, faktör 3 altında altı madde $(2,4,6,10$, 12, 14) ve faktör 4 altında ise üç madde (3, 7, 11) toplanmıştır. Buna göre faktör 1'e ait maddeler "içsel", faktör 2'ye ait maddeler "dışsal/sorumluluk", faktör 3'e ait maddeler "içe yansıtma" ve faktör 4'e ait maddeler de "ilgisizlik/kayıtsızlık" alt boyutunu oluşturmuştur. 
- Doğrulayıcı Faktör Analizi (DFA): Ölçeğin yapı geçerliğine yönelik AFA sonuçları dikkate alınarak modelin test edilmesine yönelik DFA analizinin ilk bulguları ( $x 2 / \mathrm{sd}=2.99, \quad$ RMSEA=0.059, $\mathrm{NFI}=0.96, \quad \mathrm{GFI}=0.89, \mathrm{AGFI}=0.87, \mathrm{CFI}=0.97$ ve $\mathrm{NNFI}=0.97$ ) tatmin edici düzeyde geçerli bulunmadığından, modelin hata kovaryanslarının ilişkilendirilmesine ilişkin olarak önerilen modifikasyona gidilmiştir. Modifikasyonlar madde 17 ile 18, madde 17 ile 19 ve madde 25 ile 26 arasında yapılarak model tekrar sınanmıştır. Düzeltme indeksleri ki-kare değerinde azalmaya neden olduğundan, uyum iyiliği indekslerinde de iyileşme sağlamaktadır. Düzeltme sonrası model tekrar sınandığında, modelin uygunluğu için hesaplanan $x^{2} / s d=2.23^{\prime}$ dür. $x^{2}$ değerinin serbestlik derecesine oranının $3^{\prime}$ den küçük olması mükemmel uyumu göstermektedir (Seçer, 2015). Diğer uyum iyiliği indeks değerleri ise RMSEA=0.046, GFI=0.92, $\mathrm{AGFI}=0.90, \mathrm{NFI}=0.97$; NNFI $=0.98, C F I=0.98$ olarak hesaplanmıştır. Elde edilen bu uyum indeks değerlerinin modelin oldukça iyi sınırlar içinde olduğunu göstermektedir. Diğer taraftan; DFA analizi yorumlanırken, DFA'ya göre maddelerin Lambda ( $\lambda$ ) (faktör yükü), $t$ ve $R^{2}$ değerleri de önem taşımaktadır. Bu değerler Tablo 2'de verilmiştir.

Tablo 2. DFA sonuçlarına göre standardize edilmiş lambda, $t$ ve $R^{2}$ değerleri

(Table 2. Standardized lambda, $t$ test and $\mathrm{R}^{2}$ values for CFA results)

\begin{tabular}{|c|c|c|c|c|}
\hline Faktörler & Maddeler & $\lambda$ & $t$ & $\mathrm{R}^{2}$ \\
\hline \multirow{11}{*}{$\begin{array}{l}\text { Faktör } 1 \\
\text { İçsel }\end{array}$} & 22 & 0.71 & 19.08 & 0.51 \\
\hline & 19 & 0.76 & 20.81 & 0.58 \\
\hline & 23 & 0.76 & 20.84 & 0.58 \\
\hline & 26 & 0.73 & 19.78 & 0.54 \\
\hline & 25 & 0.69 & 18.07 & 0.47 \\
\hline & 21 & 0.71 & 19.14 & 0.51 \\
\hline & 17 & 0.74 & 20.18 & 0.55 \\
\hline & 20 & 0.70 & 18.65 & 0.49 \\
\hline & 24 & 0.63 & 16.19 & 0.39 \\
\hline & 18 & 0.68 & 18.07 & 0.47 \\
\hline & 1 & 0.58 & 14.70 & 0.34 \\
\hline \multirow{6}{*}{$\begin{array}{c}\text { Faktör } 2 \\
\text { Dışsal/Sorumluluk }\end{array}$} & 13 & 0.63 & 15.79 & 0.39 \\
\hline & 5 & 0.66 & 17.03 & 0.44 \\
\hline & 15 & 0.63 & 15.87 & 0.39 \\
\hline & 8 & 0.66 & 17.03 & 0.44 \\
\hline & 16 & 0.76 & 20.55 & 0.58 \\
\hline & 9 & 0.70 & 18.43 & 0.50 \\
\hline \multirow{6}{*}{$\begin{array}{c}\text { Faktör } 3 \\
\text { İce yansıtma }\end{array}$} & 14 & 0.65 & 14.01 & 0.42 \\
\hline & 6 & 0.58 & 12.50 & 0.34 \\
\hline & 4 & 0.59 & 12.58 & 0.34 \\
\hline & 2 & 0.41 & 8.59 & 0.17 \\
\hline & 12 & 0.44 & 9.29 & 0.20 \\
\hline & 10 & 0.26 & 5.30 & 0.06 \\
\hline \multirow{3}{*}{$\begin{array}{c}\text { Faktör } 4 \\
\text { İlgisiz/Kayıtsız }\end{array}$} & 7 & 0.62 & 14.36 & 0.38 \\
\hline & 3 & 0.64 & 15.08 & 0.42 \\
\hline & 11 & 0.72 & 17.13 & 0.52 \\
\hline
\end{tabular}

Tablo 2'deki değerler incelendiğinde; maddelerin faktör yüklerini gösteren Lambda $(\lambda)$ değerlerinin 0.26 ile 0.76 arasında değiştiği görülmektedir. Bu değerler, maddelerin faktör yüklerinin kabul edilebilir düzeyde olduğuna işaret etmektedir. Gizil değişkenlerin gözlenen değişkenleri açıklama durumlarına ilişkin $t$ değerleri de .01 ve .05 düzeyinde anlamlıdır. Çokluk, Şekercioğlu ve Büyüköztürk'e (2010) göre, yapılan analizlerde manidar olmayan $t$ 
değerlerinin analiz dışı bırakılması gerektiğini ileri sürmüştür. Buna göre, modeldeki bütün maddelerin t değerlerinin anlamlı olması modelde kalmaları gerektiğine işaret etmektedir. Diğer taraftan, $\mathrm{R}^{2}$ değerlerine bakıldığında, alt faktörler tarafından maddelerde açıklanan varyans oranlarının 0.06 ile 0.58 arasında değiştiği görülmektedir. Elde edilen bulgular, gözlenen değişkenler ve örtük değişkenler arasında tek yönlü doğrusal ilişkiyi ifade eden parametrelerin istatistiksel olarak anlamlı olduğunu ortaya koymaktadır.

\subsection{Güvenirlik (Reliability)}

Disiplin Sağlama Stratejileri Ölçeği'nin güvenirliğine ilişkin Cronbach alfa iç tutarlık katsayıları hesaplanmıştır. Ölçeğin iç tutarlık katsayıları faktör 1 için.92, faktör 2 için.84, faktör 3 için . 65 ve faktör 4 için .71 olarak bulunmuştur. Ölçekten toplam puan alınmadığından ve faktörlerin biri diğerinden bağımsız olması nedeniyle bütünü için alfa değeri hesaplanmamıştır. Ölçeğin alt boyutlarını oluşturan maddelere ilişkin tanımlayıcı istatistikler, madde-toplam korelasyonları ve madde silindiğinde alfa değerlerine yönelik analiz sonuçları Tablo 3'de verilmiştir.

Tablo 3. Disiplin sağlama stratejileri ölçeği'nin betimsel

istatistikleri, madde-toplam korelasyonları ve madde silindiğinde iç tutarlılık katsayıları

(Table 3. Descriptive statistics, item-total correlations and cronbach's alpha if item deleted of the discipline sustain strategies

\begin{tabular}{|c|c|c|c|c|c|c|}
\hline Maddeler & $X$ & ss & $\begin{array}{c}\text { Madde } \\
\text { Silindiğinde } \\
\text { Ölçek } \\
\text { Ortalaması }\end{array}$ & $\begin{array}{c}\text { Madde Silindiğinde } \\
\text { Ölçek Varyansı }\end{array}$ & $\begin{array}{c}\text { Madde- } \\
\text { Toplam } \\
\text { Korelasyonu }\end{array}$ & \begin{tabular}{|c|} 
Madde \\
Silindiğind \\
e Alfa \\
Değeri
\end{tabular} \\
\hline \multicolumn{7}{|c|}{ Faktör 1 (İçsel), $\alpha=.92$} \\
\hline M1 & 2.96 & 1.46 & 31.40 & 121.60 & .54 & .91 \\
\hline M17 & 3.04 & 1.59 & 31.32 & 113.40 & .74 & .90 \\
\hline M18 & 3.25 & 1.52 & 31.12 & 116.95 & .66 & .91 \\
\hline M19 & 2.87 & 1.51 & 31.49 & 114.49 & .75 & .90 \\
\hline M20 & 3.27 & 1.41 & 31.10 & 118.89 & .66 & .91 \\
\hline M21 & 3.14 & 1.39 & 31.22 & 118.70 & .67 & .91 \\
\hline M22 & 3.09 & 1.41 & 31.28 & 118.43 & .68 & .91 \\
\hline M23 & 3.36 & 1.46 & 31.01 & 116.29 & .71 & .91 \\
\hline M24 & 2.89 & 1.39 & 31.47 & 120.94 & .60 & .91 \\
\hline M25 & 3.18 & 1.47 & 31.18 & 117.69 & .66 & .91 \\
\hline M26 & 3.32 & 1.50 & 31.05 & 116.04 & .70 & .91 \\
\hline \multicolumn{7}{|c|}{ Faktör 2 (Dışsal/Sorumluluk), $\alpha=.84$} \\
\hline M5 & 3.27 & 1.51 & 17.13 & 29.28 & .60 & .81 \\
\hline M8 & 3.71 & 1.36 & 16.69 & 30.41 & .60 & .81 \\
\hline M9 & 3.17 & 1.45 & 17.23 & 29.50 & .62 & .81 \\
\hline M13 & 3.47 & 1.42 & 16.93 & 30.14 & .59 & .81 \\
\hline M15 & 3.46 & 1.45 & 16.94 & 29.93 & .59 & .81 \\
\hline M16 & 3.32 & 1.50 & 17.08 & 28.59 & .65 & .80 \\
\hline \multicolumn{7}{|c|}{ Faktör 3 (İçe Yansıtma), $\alpha=.65$} \\
\hline M2 & 2.89 & 1.40 & 13,79 & 21.64 & .34 & .63 \\
\hline M4 & 2.68 & 1.47 & 13,99 & 20.01 & .44 & .59 \\
\hline M6 & 2.57 & 1.51 & 14,11 & 19.71 & .45 & .59 \\
\hline M10 & 2.71 & 1.38 & 13,97 & 23.19 & .22 & .67 \\
\hline M12 & 3.11 & 1.52 & 13,57 & 20.88 & .35 & .63 \\
\hline M14 & 2.72 & 1.45 & 13,95 & 19.39 & .51 & .56 \\
\hline \multicolumn{7}{|c|}{ Faktör 4 (İlgisiz Kayıtsız), $\alpha=.71$} \\
\hline M3 & 2.24 & 1.43 & 4.61 & 6.40 & .52 & .62 \\
\hline M7 & 2.29 & 1.48 & 4.56 & 6.20 & .52 & .61 \\
\hline M11 & 2.32 & 1.50 & 4.53 & 6.11 & .52 & .61 \\
\hline
\end{tabular}




\section{TARTIŞMA VE SONUÇ (DISCUSSION AND CONCLUSION)}

Bu çalışma Papaioannou (1998) tarafından geliştirilmiş Disiplin Sağlama stratejileri Ölçeği-DSSÖ (Strategies to Maintain Discipline Scale-SSDS)'nin Türkçe'ye uyarlanması amacıyla yapılmıştır. Ölçeğin yapı geçerliğini test etmek ve faktör yapısını ortaya koymak üzere yapılan Açıklayıcı Faktör Analizi (AFA) sonucunda ortaya çıkan modelin Doğrulayıcı Faktör Analizi (DFA) sonuçlarına göre; ölçeğin dört alt boyuttan ve ölçeğin özgün formuna uygun olarak toplam 26 maddeden oluştuğu anlaşılmaktadır. Ortaya konulan modelin DFA ile de doğrulandığı ve modele ilişkin uyum indekslerinin kabul edilebilir düzeyde olduğu görülmüştür. Model uyumunun kabul edilebilir olarak değerlendirilmesi için ki-kare değerinin 3'ün ve RMSEA değerinin 0.08'in altında, NFI 0.90-0.95, NNFI ve CFI 0.95-0.97, GFI 0.90-0.95 ile AGFI değerlerinin 0.85-0.90 arasında olması gerektiği bildirilmiştir (Yılmaz ve Çelik, 2009).

$\mathrm{Bu}$ çalışmadan elde edilen değerlere bakıldığında, indeks değerlerinin belirtilen aralıklarda olduğu ve modelin uyumluluğunun kabul edilebilir düzeyde olduğu söylenebilir. Özgün ölçeği geliştiren Papaioannou (1998)'nun Yunan kültüründe yaşları 10 ve 15 arasında değişen toplam 674 (N erkek=319, N klz=355) ortaokul öğrencisi ile yaptığı çalışma sonuçlarıyla bizim çalışma sonuçlarımız uyum göstermektedir. Papaioannou (1998) da özdeğeri 1'den yüksek dört alt faktör elde etmiştir. Disiplin Sağlama stratejileri ölçeği'nin geçerlik ve güvenirliğini sınamak amacıyla Gutierrez, Ruiz ve Lopez (2010) tarafından da Íspanyol kültüründe yaşları 13-17 arasında olan çocuklarla bir çalışma yapılmıştır. Onların yaptığı çalışmadan elde edilen bulgular ile bizim çalışmamızdan elde edilen bulgular arasında benzerlik bulunmaktadır.

Gutierrez, Ruiz ve Lopez tarafından yapılan DFA analizine ait ilk bulgularda tatmin edici sonuçlar elde edilememiş, ikinci kez tekrarlanan analizlerde ise elde edilen bulgular daha iyi uyum indeksleri sağlamıştır. Ancak yaptıkları çalışmada uyum indekslerini kötüleştiren iki maddenin çıkartılması ile ölçeğin orijinal dört faktörlü yapısı elde edilememiş ve sonuç olarak üç faktörlü bir yapı ile 24 maddeye sahip bir ölçek elde etmişlerdir. Bu anlamda, bizim çalışmamızda elde edilen bulgularda ise herhangi bir maddenin ölçekten çıkartılmasına gerek kalmamış ve özgün ölçeğe uygun dört faktörlü ve 26 maddeden oluşan bir yapı elde edilmiştir.

Spray (2002) tarafından yapılan çalışmada ise ölçeğe temel bileşenler faktör analizi sonuçlarına göre ölçek altı faktörlü bir yapı gösterdiği, daha faktör yük değeri.40 olarak sabitlenerek dört faktörlü bir yapı elde edilmiştir. Ancak .40'ın üzerinde 19 madde kalmış ve elde edilen ölçeğin madde sayısı azalmıştır. Ayrıca ölçeğin güvenirlik katsayıları ise .72 ile .85 arasında değişmektedir. Spray (2002) tarafından yapılan çalışma ile bizim çalışma sonuçlarımız karşılaştırıldığında, ölçeğin Türk örneklem grubunda güvenirlik katsayılarının .92 ile .65 arasında değiştiği bulunmuştur. Sonuç olarak bu çalışma ile elde edilen bulgular ışığında, Türkçe'ye uyarlaması yapılan Disiplin Sağlama Stratejileri Ölçeği'nin pskometrik parametreleri dikkate alındığında; geçerli ve güvenilir bir ölçme aracı olarak 10-15 yaş grubu için beden eğitimi derslerinde kullanılabileceği söylenebilir. 


\section{KAYNAKLAR (REFERENCES)}

1. Aydın, B., (2006). Öğretmenlerin Kendi Sınıf Disiplin Sistemlerini Oluşturması. Sosyal Bilimler Araştırmaları Dergisi, $2,19-32$.

2. Başar, H., (2001). Sınıf Yönetimi. 5. Baskı, Ankara: Pegem Yayıncılık.

3. Charles, C.M., (1996). Building Classroom Discipline. New York: Longman.

4. Çokluk, Ö., Şekercioğlu, G. ve Büyüköztürk, Ş., (2010). Sosyal Bilimler için Çok Değişkenli İstatistik: SPSS ve LISREL Uygulamaları. Ankara: Pegem Yayıncılık.

5. Gliner, J.A., Morgan, G.A., and Leech, N.L., (2015). Research Methods In Applied Setting. New York: Routledge.

6. Gordon, T., (2000). Çocukta Dış Disiplin mi? İç Disiplin mi?. (Çeviren: Emel Aksay). İstanbul: Sistem Yayıncılık.

7. Gutiérrez, M., Ruiz, L.M., and López, E., (2010). Perceptions of Motivational Climate and Teachers' Strategies to Sustain Discipline as Predictors of Intrinsic Motivation in Physical Education. The Spanish Journal of Psychology, $13(2)$ : 597-608.

8. Gündüz, H.B., (2004). Eğitim Okul ve Sınıf Yönetimi. Ankara: Asil Yayıncılık.

9. Humphreys, T., (2001). Disiplin nedir? Ne değildir? 2. Baskı, Çev. Berat Çelik. Ístanbul: Epsilon Yayıncılık.

10. Jöreskog, K.G. and Sörbom, D., (2004). LISREL 8.7 for Windows [Computer software]. Lincolnwood, IL: Scientific Software International, Inc.

11. Papaioannou, A., (1998). Goal Perspectives, Reasons for Being Disciplined and Self-Reported Discipline in Physical Education Lessons. Journal of Teaching in Physical Education, 17, 421-441.

12. Sadık, F., (2016). Okul Öncesinde Sınıf Yönetimi: Disiplin Yaklaşımları. (Ed. Yaşare Aktaş Arnas ve Fatma Sadık). 1. Baskı, Ankara: Pegem Akademi.

13. Seçer, İ., (2015). SPSS ve Lisrea ile Pratik Veri Analizi. 2. Baskı, Anakara: Anı Yayıncılık.

14. Spray, C., (2002). Motivational Climate and Perceived Strategies to Sustain Pupils' Discipline in Physical Education. European Physical Education Review, 8, 5-20.

15. Tertemiz, N., (2003). Sınıf Yönetimi ve Disiplin: Sınıf Yönetiminde Yeni Yaklaşımlar. (Ed: Leyla Küçükahmet) Ankara: Nobel Yayıncılık.

16. Ünlü, H. ve Aydos, L., (2008). Beden Eğitimi Dersinde Sınıf Yönetimi. Uluslararası İnsan Bilimleri Dergisi. 5(1), 1-7.

17. Yaşar, M., (2016). Okul Öncesinde Sınıf Yönetimi: Sınıf Yönetimini Etkileyen Çevresel Unsurlar. (Ed. Yaşare Aktaş Arnas ve Fatma Sadık). 1. Baskı, Ankara: Pegem Akademi.

18. Yılmaz, V. ve Çelik, H.E., (2009). Lisrel ile Yapısal Eşitlik Modellemesi: Temel Kavramlar, Uygulamalar, Programlama, Ankara: Pegem Akademi Yayıncılık.

19. Zounhia, K., Hatziharistos, D., and Emmanouel, K., (2003). Greek Secondary School Pupils' Perceived Reasons for Behaving Appropriately and Perceived Teachers' Strategies to Maintain Discipline. Educational Review, 55(3), 289-303. 


\section{EK (APPANDIX)}

Disiplin Stratejileri Sağlama Ölçeği Maddeleri

\begin{tabular}{|c|c|}
\hline & $\begin{array}{l}\text { Beden eğitimi öğretmeni disiplini nasıl sağlar? } \\
\text { Beden eğitimi dersinde, disiplini sağlamak için öğretmen .... }\end{array}$ \\
\hline 1 & Dersi ilginç hale getirerek dikkatimizi canlı tutar. \\
\hline 2 & Eğer uygun davranmazsak, kendimizi kötü hissetmemize neden olur. \\
\hline 3 & Disiplini sağlamak için hiçbir şey yapmaz. \\
\hline 4 & Uygunsuz davrandığımızda bizi cezalandırmakla korkutur. \\
\hline 5 & Yeni beceri ve oyunlar öğreterek dikkatimizi canlı tutar. \\
\hline 6 & Uygun davranmadığımızda bizi utandırır. \\
\hline 7 & Nasıl davrandığımızı umursamaz/aldırmaz. \\
\hline 8 & Bize kurallara uygun davranmamız gerektiğini hatırlatır \\
\hline 9 & Nasıl geliştiğimize dikkatimizi çekerek dersi öğretir. \\
\hline 10 & $\begin{array}{l}\text { Bize sadece uygun şekilde davrananların iyi öğrenci } \\
\text { sayıldıklarını hatırlatır. }\end{array}$ \\
\hline 11 & $\begin{array}{l}\text { Ben beden eğitimi derslerinde gerçekten hiç bir disiplinin } \\
\text { olmadığını düşünüyorum. }\end{array}$ \\
\hline 12 & Kaytaranlara/oyalananlara bağırır. \\
\hline 13 & $\begin{array}{l}\text { Beden eğitimi dersinde hareketleri iyi yapmanın önemli olduğuna } \\
\text { bizi inandırır. }\end{array}$ \\
\hline 14 & Düzgün davranmadığımızda kendimizi kötü hissetmemize neden olur. \\
\hline 15 & Bize okul kurallarını hatırlatır. \\
\hline 16 & $\begin{array}{l}\text { Becerilerimizi geliştirmek için çabalamamızı sağlayarak } \\
\text { dikkatimizi canlı tutar. }\end{array}$ \\
\hline 17 & Dersi eğlenceli hale getirir. \\
\hline 18 & Beden eğitimi dersinden hoşlanmamızı sağlar. \\
\hline 19 & Dersi heyecanlı/ilginç hale getirir. \\
\hline 20 & Davranışlarımızdan sorumlu olmamıza yardım eder. \\
\hline 21 & Dersin istediğimiz bir bölümünde sorumluluk almamıza yardım eder. \\
\hline 22 & Kendi gelişimimizden sorumlu olmamıza yardım eder. \\
\hline 23 & Sorumluluk sahibi öğrenciler olmamıza yardım eder. \\
\hline 24 & $\begin{array}{l}\text { Beden eğitimi dersinde diğer öğrencilerin gelişimini anlamamıza } \\
\text { yardım eder. }\end{array}$ \\
\hline 25 & Öğrenciler arasında anlayışlı olma ve işbirliğini teşvik eder. \\
\hline 26 & Öğrenmeye ve birbirimize yardımcı olmaya bizi teşvik eder. \\
\hline
\end{tabular}

